\title{
MAST1 wt Allele
}

National Cancer Institute

\section{Source}

National Cancer Institute. MAST1 wt Allele. NCI Thesaurus. Code C101456.

Human MAST 1 wild-type allele is located in the vicinity of 19p13.2 and is approximately

$37 \mathrm{~kb}$ in length. This allele, which encodes microtubule-associated serine/threonineprotein kinase 1 protein, is involved in both protein phosphorylation and cytoskeletal structure. 